\title{
Ontogenetic changes in phototactic behavior during metamorphosis of artificially reared Japanese eel Anguilla japonica larvae
}

\author{
Yoshiaki Yamada $^{1, *}$, Akihiro Okamura ${ }^{1}$, Naomi Mikawa ${ }^{1}$, Tomoko Utoh ${ }^{1}$, \\ Noriyuki Horie $^{1}$, Satoru Tanaka ${ }^{1}$, Michael J. Miller ${ }^{2}$, Katsumi Tsukamoto ${ }^{1,2}$ \\ ${ }^{1}$ IRAGO Institute, Ehima, Tahara Aichi 441-3605, Japan \\ ${ }^{2}$ Ocean Research Institute, The University of Tokyo, Minamidai 1-15-1, Tokyo 164-8639, Japan
}

\begin{abstract}
The larvae of anguillid eels are termed leptocephali, among other reasons, because they differ greatly in morphology and physiology from other fish larvae. Leptocephali grow to large sizes but are transparent and fragile and have an unusual feeding strategy, so their behavior or ecology has rarely been studied. We used leptocephali, metamorphosing larvae and glass eels reared artificially from eggs to study the ontogenetic change in phototaxis in Japanese eel Anguilla japonica. By studying the early life history of this eel, our intent was to learn more about behavioral mechanisms associated with their vertical migration in the ocean and their long migration from the offshore spawning area to coastal waters. Horizontal distribution experiments found a clear negative phototaxis in the leptocephalus and metamorphosing larval stages, but no phototaxis was detected after metamorphosis into glass eels. Vertical distribution experiments found that overhead lighting caused downward movement in leptocephali and metamorphosing larvae. When kept in darkness, leptocephali and metamorphosing larvae were distributed near the surface layer at night and at the bottom during daylight hours, suggesting an endogenous circadian rhythm that may control their diel vertical migration. Glass eels exhibited benthic distribution under any light conditions (0.0039 to $3.9 \mu \mathrm{mol}$ quanta $\mathrm{m}^{-2} \mathrm{~s}^{-1}$ ), but showed random vertical distribution in darkness during both daytime and nighttime, a behavior which appeared to be controlled only by light. Swimming speeds of leptocephali during horizontal movement and rising behavior were significantly greater than during diving behavior. These swimming behaviors and ontogenetic changes in phototactic behavior may help regulate the vertical distribution and inshore migration of anguillid eel larvae in the ocean.
\end{abstract}

KEY WORDS: Fish larvae $\cdot$ Phototaxis $\cdot$ Vertical migration $\cdot$ Anguillid eels $\cdot$ Anguilla japonica Resale or republication not permitted without written consent of the publisher

\section{INTRODUCTION}

The long migrations of freshwater eels of the genus Anguilla between their spawning area thousands of kilometers offshore in the ocean and their freshwater habitat are one of the well-known examples of remarkable animal migrations (Tsukamoto 1992). Anguillid eel larvae hatch at small sizes $(3.7 \mathrm{~mm}$ total length [TL] for Japanese eel A. japonica, Tanaka et al. 2003) and become transparent leaf-like leptocephalus larvae that reach sizes $>50 \mathrm{~mm}$ (50 to $60 \mathrm{~mm}$ TL for
A. japonica, Mochioka 2003). These larvae are transported away from their offshore adult spawning areas by currents while growing gradually to reach the size at which metamorphosis occurs. After metamorphosis, which takes about 3 wk, (Otake et al. 1994, Arai et al. 1997), transparent early juvenile eels, or so-called glass eels, migrate to the estuaries of rivers where they recruit (Tsukamoto 1992, Kimura et al. 1994). Recent research has begun to reveal some aspects of the complex biology and the long larval migrations of these unusual fishes (Kimura et al. 1994, McCleave 
2003, Tsukamoto et al. 2003, Otake et al. 2006). Studies on the spawning area of the Japanese eel $A$. japonica based on catches of small larvae (Tsukamoto 1992, 2006, Tsukamoto et al. 2003), the transportation routes of the leptocephali (Kimura et al. 1994, 1999) and the recruitment mechanisms of the glass eels that enter freshwater (Tsukamoto 1990, Cheng \& Tzeng 1996) have been the subjects of research cruises and otolith analyses of the early life history stages of this species.

In the Pacific Ocean, Japanese eel larvae are passively transported westward by the North Equatorial Current (NEC) and then northward by the Kuroshio Current; they thus have to transfer between these 2 major currents for successful recruitment to their freshwater habitats in eastern Asia (Kimura et al. 1994, Otake et al. 2006). However, this oceanic larval migration of leptocephali is probably not entirely passive, but includes some active behavioral components, such as vertical migration and swimming activity. Leptocephali appear to start vertical migration while moving west in the NEC, where individuals (10 to $20 \mathrm{~mm}$ TL) have been caught at depths of 50 to $100 \mathrm{~m}$ at night, and 100 to $200 \mathrm{~m}$ during daytime (Otake et al. 1998). Moreover, large leptocephali were observed at shallower depths than were small leptocephali at night (Kajihara et al. 1988), which suggests nighttime distribution becomes shallower with growth. Kimura et al. (1994) hypothesized that this distribution in shallower depths enables leptocephali to use the slight northward flow caused by Ekman transport resulting from the trade winds in the region; this would help them transfer between the currents when they come up to the surface layer at night. This vertical migration of leptocephali at this stage of their life history may be critical in enabling them to avoid being transported beyond their species' range when the NEC bifurcates into the Kuroshio Current and the southward-flowing Mindanao Current (Kimura et al. 1994, Kimura \& Tsukamoto 2006).

Diel vertical migration is also observed in a wide range of both freshwater and marine zooplankton taxa (Lampert 1989, Hays 2003, Pearre 2003) and is a complex phenomenon affected by many endogenous and exogenous factors such as light, trophic state, buoyancy, hydrostatic pressure, salinity, temperature, water movement and circadian rhythms (Crisp 1974, Stancyk \& Feller 1986, Naylor 2006). Phototaxis triggered by light stimuli appears to be the primary behavioral mechanism-among many other minor factorsunderlying diel vertical migration (Ringelberg 1995, 1999). Diel vertical migration in leptocephali is probably also controlled by light as it is in other fishes, since this migration appears to coincide with sunrise and sunset (Blaxter 1975, Castonguay \& McCleave 1987).
However, little is known about the behavioral mechanisms of vertical migration and inshore migration of anguillid eels. Behavioral studies of leptocephali have been extremely limited, since these fragile larvae are easily damaged during net sampling and previous researchers have thus rarely had the opportunity to observe the behaviors of live leptocephali. Leptocephali caught in coastal waters are usually more adaptable to transport to the laboratory for at least short periods of observation, so a few studies have been done on feeding behavior (Mochioka et al. 1993) and swimming ability (Wuenschel \& Able 2008). Recently, however, Tanaka et al. (2003) succeeded in rearing leptocephali through their larval developmental stages and into glass eels from fertilized eggs obtained from artificially matured adult eels. This progress has enabled us to observe the behaviors of healthy leptocephali and metamorphosing larvae in the laboratory.

In this study, we focused on the ontogenetic change in phototaxis in the 3 early life history stages of Japanese eels to understand how this behavioral mechanism may relate to their vertical migration in the ocean and their migration from offshore to inshore coastal waters. The findings of this first experiment about the behavior of eel leptocephali in captivity provide a new opportunity to evaluate the behavioral ecology of these poorly understood larvae.

\section{MATERIALS AND METHODS}

Fishes. Japanese eels were reared from glass eels and feminized by being fed a diet containing estradiol$17 \beta$ (Tachiki \& Nakagawa 1993). Three feminized eels were matured artificially by administrating a saline suspension of chum salmon Oncorhynchus keta pituitary extract ( $20 \mathrm{mg} \mathrm{kg}^{-1}$ body weight) once a week following the methods of Horie et al. (2008). These females were paired with males that had been matured using human chorionic gonadotropin (HCG) injections. After spawning, fertilized eggs were collected and kept in seawater $\left(21^{\circ} \mathrm{C}, 32\right)$ until hatching, and hatched larvae were kept in the same seawater for $8 \mathrm{~d}$ until functional mouth differentiation occurred. Larvae were fed with a slurry-type diet mainly composed of shark egg yolk, soybean peptide and krill extract (Tanaka et al. 2003).

Larvae with different hatching dates were reared separately from each other in order to ensure their exact age was always known. Simulating the dark environment in nature, weak lights $(0.6$ to $1.3 \mu \mathrm{mol}$ quanta $\mathrm{m}^{-2} \mathrm{~s}^{-1}$ ) were kept on during daytime (09:00 to $18: 00 \mathrm{~h}$ ), and the light intensity was temporarily increased to ca. $10.0 \mu \mathrm{mol}$ quanta $\mathrm{m}^{-2} \mathrm{~s}^{-1}$ only during 
the 5 feeding times (1 h each) per day (09:00, 11:00, 13:00, 15:00 and 17:00 h). Metamorphosis began $225 \mathrm{~d}$ after hatching, and the glass eel stage was reached by some individuals by 235 to 328 d after hatching. We used 19 leptocephali, 17 leptocephali undergoing metamorphosis and 18 glass eels in the study. These fish showed no signs of weakness, deformity or abnormal behavior.

After the experiments, we measured TL, body depth (BD) and preanal length (PAL) of the fish and categorized their growth stages as follows - PAL/TL > 0.7: leptocephalus (Mochioka 2003); PAL/TL $\leq 0.7$ and BD/ $\mathrm{TL} \geq 0.1$ : metamorphosing leptocephalus; and BD/TL < 0.1: glass eel. Age, TL, BD/TL and PAL/TL of fish used in this study are shown in Table 1. All of the experiments were performed within a 2 mo period.

Horizontal distribution experiment. This experiment examined phototaxis and its threshold of light intensity in leptocephali, metamorphosing leptocephali and glass eels. We used Japanese eel of approximately the same size (45 to $60 \mathrm{~mm}$ TL) and age (305 to $306 \mathrm{~d}$ ) but at these 3 different developmental stages for the horizontal distribution experiment: i.e. 5 leptocephali (45 to $56 \mathrm{~mm}$ ), 6 metamorphosing leptocephali (50 to $60 \mathrm{~mm}$ ) and 6 glass eels (53 to $60 \mathrm{~mm}$ ). A wide tank $(90 \times 10 \times 10 \mathrm{~cm})$ made of transparent acrylic plastic was used. Water depth was $8 \mathrm{~cm}$. We used $40 \mathrm{~W}$ incandescent light bulbs (LW100V36W, Matsushita Electric Industrial) set on either side of the tank as a light source, because the intensity of illuminance is easily adjustable with this type of bulb. Illuminance was regulated by a power controller (PC-31, Taiyo Electric Industry). The light intensity of the bulb was measured by a light quantum meter (UIZ-PAR, Wizin) and intensities from 0 to $3.9 \mu \mathrm{mol}$ quanta $\mathrm{m}^{-2} \mathrm{~s}^{-1}$ were used. The maximum light intensity (3.9 $\mu \mathrm{mol}$ quanta $\mathrm{m}^{-2} \mathrm{~s}^{-1}$ ) in this study was determined in preliminary experiments in which leptocephali exhibited clear negative phototaxis at this level of illuminance. For comparison among measures of light intensity, a light level of $3.9 \mu \mathrm{mol}$ quanta $\mathrm{m}^{-2} \mathrm{~s}^{-1}$ coincided with 200 lux in our experimental settings. Water temperature in the tank was maintained at $21^{\circ} \mathrm{C}$, the same temperature as the rearing temperature of the larvae. The distribution of fish was examined by eye or with a highly sensitive charge-coupled device (CCD) video camera (WAT$100 \mathrm{~N}$, Watec) with an infrared light-emitting diode (LED) lamp illumination.

Either 5 or 6 fish were introduced into the tank and acclimatized to an overhead light intensity level of $3.9 \mu \mathrm{mol}$ quanta $\mathrm{m}^{-2} \mathrm{~s}^{-1}$ (at the water surface) for $10 \mathrm{~min}$ before test sessions. The test sessions consisted of 5 different light intensity phases: 0, 0.0039, 0.039, $0.39,3.9 \mu \mathrm{mol}$ quanta $\mathrm{m}^{-2} \mathrm{~s}^{-1}$ (light fixed on the right wall of the tank) from the right, and 1 phase of $3.9 \mu \mathrm{mol}$ quanta $\mathrm{m}^{-2} \mathrm{~s}^{-1}$ (light fixed on the left wall) from the left (each $10 \mathrm{~min}$ ). In a preliminary experiment, leptocephali avoided strong light $\left(3.9 \mu \mathrm{mol}\right.$ quanta $\left.\mathrm{m}^{-2} \mathrm{~s}^{-1}\right)$ from one side and moved into the dark area on the opposite side of the tank. To avoid the behavioral effect of the previous light intensity phase, fish were subjected to a $3.9 \mu \mathrm{mol}$ quanta $\mathrm{m}^{-2} \mathrm{~s}^{-1}$ phase for $5 \mathrm{~min}$ from the left before each right-hand lighting phase, except between the right-hand $3.9 \mu \mathrm{mol}$ quanta $\mathrm{m}^{-2} \mathrm{~s}^{-1}$ and left-hand $3.9 \mu$ mol quanta $\mathrm{m}^{-2} \mathrm{~s}^{-1}$ phases. This treatment canceled the previous distribution pattern of leptocephali and drove them to the initial position (right side of the tank). It was not effective for glass eels, because they did not exhibit any phototaxis. However, we gave glass eels this treatment to ensure the same experimental conditions for each of the larval developmental stages. Each test session with 5 different light intensity phases and distribution-canceling phases took ca. $100 \mathrm{~min}$ in total.

For data analysis, the horizontal range was divided into 3 areas as follows: left $(0$ to $30 \mathrm{~cm}$ from the left side), right ( 0 to $30 \mathrm{~cm}$ from the right side), and middle (30 $\mathrm{cm}$ area between left and right areas). The area in which individual fish were distributed was recorded at the end of each of the phases.

Table 1. Anguilla japonica. Age and morphological characteristics of the leptocephali, metamorphosing leptocephali and glass eels used in this study. Data are means \pm SD

\begin{tabular}{|lccccc|}
\hline & $\mathrm{n}$ & Age $(\mathrm{d})$ & Total length $(\mathrm{mm})$ & $\begin{array}{c}\text { Body depth/ } \\
\text { total length }\end{array}$ & $\begin{array}{c}\text { Preanal length/ } \\
\text { total length }\end{array}$ \\
\hline Horizontal distribution experiments & & & & & \\
Leptocephalus & 5 & 305 & $51.8 \pm 4.0$ & $0.22 \pm 0.03$ & $0.75 \pm 0.04$ \\
$\begin{array}{l}\text { Metamorphosing leptocephalus } \\
\text { Glass eel }\end{array}$ & 6 & 306 & $55.0 \pm 5.0$ & $0.18 \pm 0.03$ & $0.51 \pm 0.08$ \\
Vertical distribution experiments & 6 & 306 & $52.2 \pm 3.7$ & $0.07 \pm 0.01$ & $0.42 \pm 0.03$ \\
$\begin{array}{l}\text { Leptocephalus } \\
\text { Metamorphosing leptocephalus }\end{array}$ & 14 & $243-295$ & $50.6 \pm 7.1$ & & \\
Glass eel & 11 & $220-301$ & $54.2 \pm 5.1$ & $0.20 \pm 0.03$ & $0.75 \pm 0.04$ \\
& 12 & $251-319$ & $49.9 \pm 4.5$ & $0.07 \pm 0.01$ & $0.50 \pm 0.04$ \\
\hline
\end{tabular}


Vertical distribution experiment. We used 14 leptocephali (30 to $60 \mathrm{~mm} \mathrm{TL}$ ), 11 metamorphosing leptocephali ( 43 to $65 \mathrm{~mm}$ TL) and 12 glass eels ( 45 to $58 \mathrm{~mm}$ TL) in the vertical distribution experiment. A tall tank $(30 \times 10 \times 92 \mathrm{~cm})$ made of transparent acrylic plastic was used. Water depth in the tank was $90 \mathrm{~cm}$. An incandescent light bulb $(100 \mathrm{~W})$ was set $10 \mathrm{~cm}$ above the water surface. Light intensity ranged from 0 to $3.9 \mu \mathrm{mol}$ quanta $\mathrm{m}^{-2} \mathrm{~s}^{-1}$ at the water surface. Tests were carried out in a dark room both during the day (12:00 to $17: 00 \mathrm{~h})$ and night (18:00 to $22: 00 \mathrm{~h})$ to learn about the potential influence of a biological clock on the vertical distribution. The distribution of fish in the tank was examined by eye or with highly sensitive CCD video cameras. Water temperature in the tank was maintained at $21^{\circ} \mathrm{C}$ in all experiments.

Either 3 or 4 fish were introduced into the tank and acclimatized to an overhead $3.9 \mu \mathrm{mol}$ quanta $\mathrm{m}^{-2} \mathrm{~s}^{-1}$ condition for $10 \mathrm{~min}$ before each test session was started. Each test session consisted of 5 lighting phases of $0,0.0039,0.039,0.39$ and $3.9 \mu \mathrm{mol}$ quanta $\mathrm{m}^{-2} \mathrm{~s}^{-1}$. Each phase was maintained for $15 \mathrm{~min}$. Between 2 successive phases, fish were subjected to $0 \mu \mathrm{mol}$ quanta $\mathrm{m}^{-2} \mathrm{~s}^{-1}$ for 10 min to cancel the distribution effect of the previous light intensity phase. Each test session consisted of 5 different light intensity phases and distribution-canceling phases lasting a total of about $130 \mathrm{~min}$.

For data analysis, depth range was divided into 4 layers as follows: surface layer ( 0 to $5 \mathrm{~cm}$ from the water surface), upper layer ( 5 to $45 \mathrm{~cm}$ from the surface), lower layer ( 45 to $85 \mathrm{~cm}$ from the surface) and bottom layer ( 85 to $90 \mathrm{~cm}$ from the surface). The layer in which individual fish were distributed was recorded at the end of each experimental phase.

Swimming speed. We measured 3 types of swimming speeds of leptocephali using video recordings from the above experiments to estimate the time required for diel vertical migration in the ocean: (1) swimming speed during rising movements observed when the lighting condition was changed from $3.9 \mu \mathrm{mol}$ quanta $\mathrm{m}^{-2} \mathrm{~s}^{-1}$ overhead lighting to $0 \mu \mathrm{mol}$ quanta $\mathrm{m}^{-2} \mathrm{~s}^{-1}$ (vertical distribution experiment, night time), (2) swimming speed during diving movements when the lighting condition was changed from $0 \mu \mathrm{mol}$ quanta $\mathrm{m}^{-2} \mathrm{~s}^{-1}$ to $3.9 \mu \mathrm{mol}$ quanta $\mathrm{m}^{-2} \mathrm{~s}^{-1}$ overhead lighting (vertical distribution experiment, night time), (3) swimming speed during side movements when the $3.9 \mu \mathrm{mol}$ quanta $\mathrm{m}^{-2} \mathrm{~s}^{-1}$ left side lighting was changed to $3.9 \mu \mathrm{mol}$ quanta $\mathrm{m}^{-2} \mathrm{~s}^{-1}$ on the right. The movements of the leptocephali were easily distinguishable due to the continuous infared LED illumination, even when there was no other light source. Swimming speeds were calculated by swimming distance and time when fish swam in a straight line over a distance of $>30 \mathrm{~cm}$.
Statistical analyses. Fisher's exact tests were used to check for differences between the actual fish distribution and the null hypothesis, i.e. that fish were distributed evenly. Swimming speed data of larvae were analyzed using the nonparametric Kruskal-Wallis test followed by comparisons with Dunn's multiple comparison test when significant differences were found. The swimming speeds are presented as means \pm SD $(n$, median, range). $\mathrm{R}$ software was used for statistical analyses.

\section{RESULTS}

\section{Horizontal distribution experiment}

At the beginning of the experiments with the leptocephalus stage (overhead $3.9 \mu \mathrm{mol}$ quanta $\mathrm{m}^{-2} \mathrm{~s}^{-1}$ ), all fish were intensely beating their tails, with their heads pressed against the bottom of the tank, and they exhibited a random distribution over the 3 horizontal areas of the tank (left, middle and right). Several minutes later they exhibited slower tail-beats, which were judged to be the completion of a short-term acclimation period before all experiments, when the larvae were newly introduced to the tank.

When a $3.9 \mu \mathrm{mol}$ quanta $\mathrm{m}^{-2} \mathrm{~s}^{-1}$ light was irradiated from the left (initial distribution-resetting step), leptocephali turned their heads toward the opposite side to swim into darker areas, keeping their body axis horizontal or slanted while their head contacted the bottom. All larvae were distributed in the dark right side of the tank within $3 \mathrm{~min}$. After this 5 min distributionresetting step, the light was turned off and the righthand lighting phases were initiated.

In darkness $\left(0 \mu \mathrm{mol}\right.$ quanta $\left.\mathrm{m}^{-2} \mathrm{~s}^{-1}\right)$, leptocephali were distributed randomly throughout the tank ( $p>$ 0.84, Fisher's exact test) (Fig. 1a). Under 0.0039 and $0.039 \mu \mathrm{mol}$ quanta $\mathrm{m}^{-2} \mathrm{~s}^{-1}$ light conditions with the light positioned at the right side of the tank, fish were distributed widely from left to right, and exhibited no differences among the 3 areas ( $p>0.35$, Fisher's exact test, Fig. 1b,c). However, under 0.39 and $3.9 \mu \mathrm{mol}$ quanta $\mathrm{m}^{-2} \mathrm{~s}^{-1}$ light intensity from the right, all fish were distributed in the darker left side $(p<0.01$, Fisher's exact test, Fig. 1d,e). Similarly, during the $3.9 \mu \mathrm{mol}$ quanta $\mathrm{m}^{-2} \mathrm{~s}^{-1}$ phase with light from the left, all fish were distributed in the dark right area $(p<0.01$, Fisher's exact test, Fig. 1f). These distributions indicated a distinct negative phototaxis of leptocephali.

In the metamorphosing stage, the horizontal distributions were generally similar to those observed in leptocephali, but the threshold of light intensity at which metamorphosing leptocephali expressed nega- 


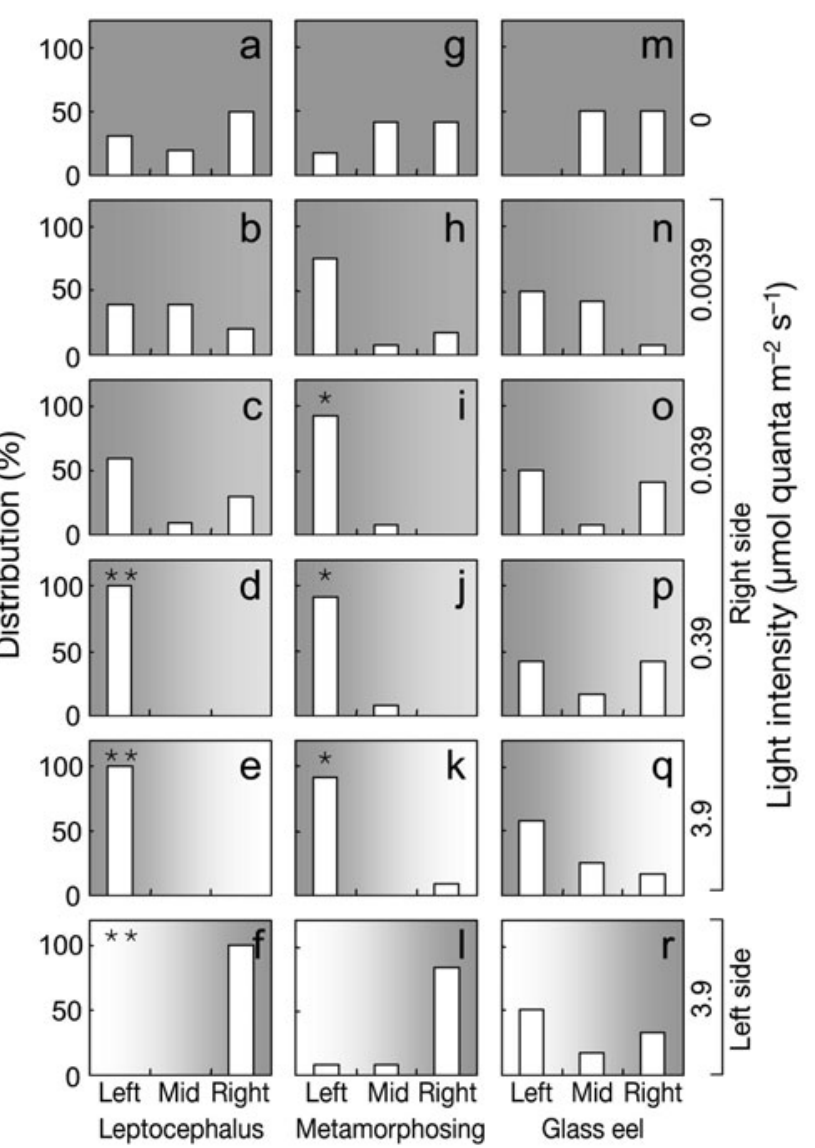

Fig. 1. Anguilla japonica. Horizontal distribution of the leptocephali, metamorphosing larvae and glass eels in response to a light stimulus from the right or left side of the test tank: (a to f) leptocephali, ( $\mathrm{g}$ to $\mathrm{l}$ ) metamorphosing larvae, ( $\mathrm{m}$ to $\mathrm{r}$ ) glass eels. The top 3 panels ( $\mathrm{a}, \mathrm{g}$ and $\mathrm{m}$ ) show the distributions in darkness, and the bottom 3 panels (f, $l$ and $r$ ) show the distributions with the light source on the left side of the tank. The remaining panels show the distribution with the light coming from the right. Significance of skewed distributions (Fisher's exact test) is shown by ${ }^{*}(p<0.05)$ or ${ }^{* *}(p<0.01)$. There were no significant skewed distributions in the graphs without asterisks

tive phototaxis was lower than for leptocephali. In darkness $\left(0\right.$ umol quanta $\left.\mathrm{m}^{-2} \mathrm{~s}^{-1}\right)$, metamorphosing leptocephali were distributed widely from left to right, exhibiting no significant distribution pattern $(\mathrm{p}>0.76$, Fisher's exact test, Fig. 1g). At a 0.0039 umol quanta $\mathrm{m}^{-2} \mathrm{~s}^{-1}$ light level, metamorphosing leptocephali were mostly distributed in the dark left side of the tank, although the distribution was not significant ( $\mathrm{p}>0.16$, Fisher's exact test, Fig. 1h). However, under 0.039 to $3.9 \mu \mathrm{mol}$ quanta $\mathrm{m}^{-2} \mathrm{~s}^{-1}$ light intensity levels, fish exhibited a significantly skewed distribution to the dark side, which indicated that they had a strong negative phototactic response $(\mathrm{p}<0.02$, Fisher's exact test, Fig. 1i-k). In contrast to leptocephali, there was a sig- nificant difference in distribution at $0.039 \mu \mathrm{mol}$ quanta $\mathrm{m}^{-2} \mathrm{~s}^{-1}$ (Fig. 1i) for the metamorphosing stage stage (Fig. 1c). This difference may be due to an increased development of the sensitivity of the eyes in metamorphosing leptocephali.

Moreover, unlike leptocephali, not all of the metamorphosing leptocephali exhibited complete negative phototaxis at 0.39 and $3.9 \mu \mathrm{mol}$ quanta $\mathrm{m}^{-2} \mathrm{~s}^{-1}$ (Fig. $1 \mathrm{j}, \mathrm{k}$ ), because the experimental group of 6 metamorphosing larvae included 1 advanced stage metamorphosing individual $(\mathrm{PAL} / \mathrm{TL}=0.42, \mathrm{BD} / \mathrm{TL}=0.12$ ) which had almost reached the glass eel stage and moved around all areas of the tank.

At the glass eel stage, fish exhibited a completely different type of behavioral response to photic stimuli in the horizontal distribution experiment than did the leptocephalus and metamorphosing leptocephalus stages, not exhibiting any phototactic response. Most glass eels were observed to just lie on the bottom of the tank, and they exhibited no significant distribution under any lighting directions or intensities $(p>0.13$, Fisher's exact test, Fig. 1m-r). Therefore, the glass eels exhibited a clear lack of any negative or positive phototactic response.

\section{Vertical distribution experiment}

At the leptocephalus stage, fish exhibited a significant bottom-skewed distribution ( $p<0.01$, Fisher's exact test) at 0.039 to $3.9 \mu \mathrm{mol}$ quanta $\mathrm{m}^{-2} \mathrm{~s}^{-1}$ light intensity levels during daytime (Fig. 2c-e, white bars). This tendency was more distinct at higher light intensities, when no fish were observed in the upper layers, indicating an apparent negative phototaxis. In darkness $\left(0 \mu \mathrm{mol}\right.$ quanta $\left.\mathrm{m}^{-2} \mathrm{~s}^{-1}\right)$, fish were distributed widely from the surface to the bottom ( $p>0.45$, Fisher's exact test), although there were more fish distributed in the bottom layer (Fig. 2a, white bars).

In the nighttime experiment, a similar bottomskewed distribution was observed at 0.039 to $3.9 \mu \mathrm{mol}$ quanta $\mathrm{m}^{-2} \mathrm{~s}^{-1}$ light intensities $(\mathrm{p}<0.03$, Fisher's exact test, Fig. 2c-e, black bars) except at $0.0039 \mu \mathrm{mol}$ quanta $\mathrm{m}^{-2} \mathrm{~s}^{-1}(\mathrm{p}>0.62$, Fisher's exact test, Fig. 2b, black bar). In darkness ( $0 \mu$ mol quanta $\left.\mathrm{m}^{-2} \mathrm{~s}^{-1}\right)$, more fish were distributed in the surface layer, although this distribution was not significant ( $p>0.09$, Fisher's exact test, Fig. 2a, black bars). However, there was a significant difference in distributions between day and night ( $p<0.05$, Fisher's exact test). The threshold of light intensity for a bottom-skewed distribution appeared to be between 0.0039 and $0.039 \mu \mathrm{mol}$ quanta $\mathrm{m}^{-2} \mathrm{~s}^{-1}$ (Fig. 2a-c).

At the metamorphosing stage, the vertical distributions were similar to those of the leptocephalus stage. 


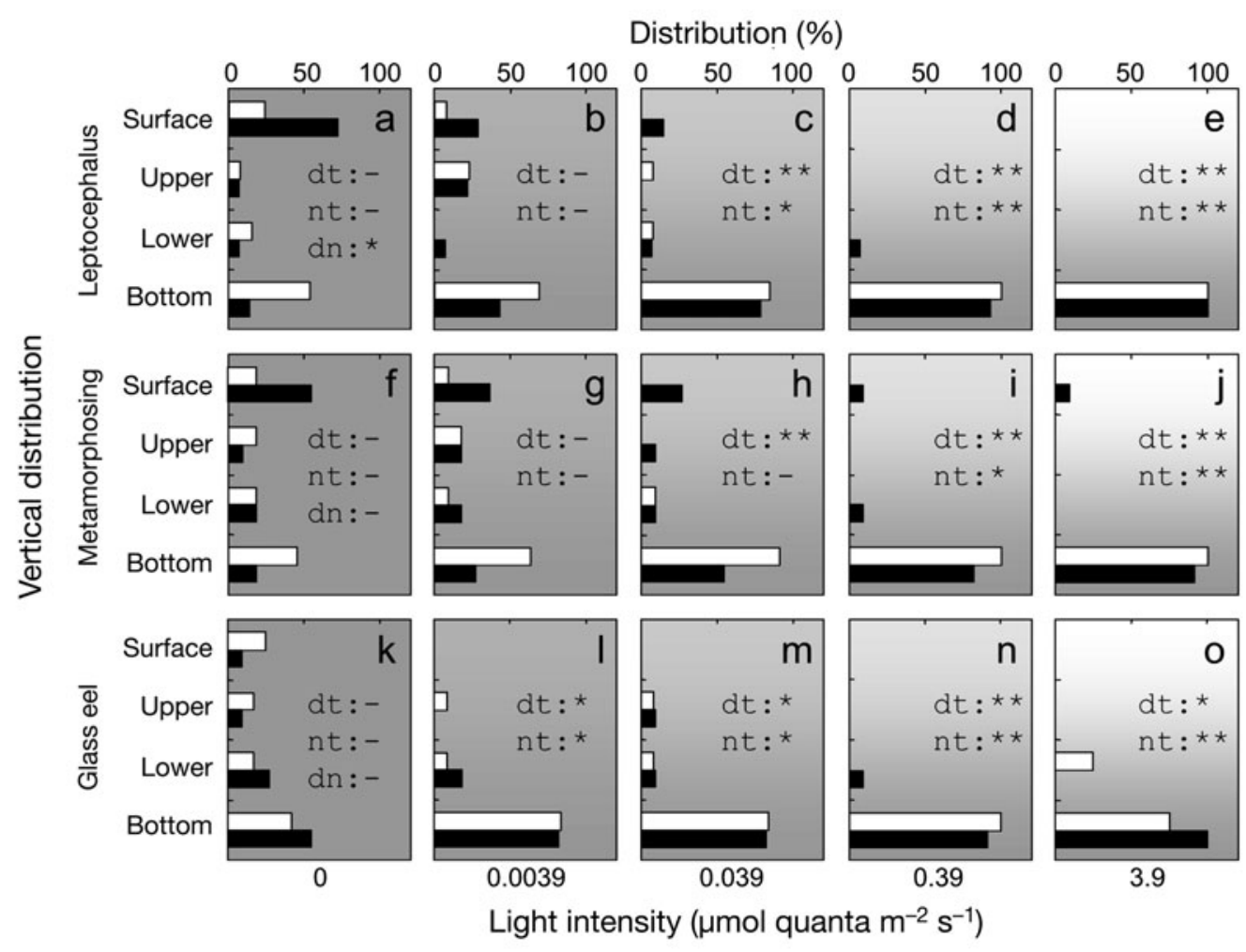

Fig. 2. Anguilla japonica. Vertical distribution of leptocephali, metamorphosing leptocephali and glass eels in response to overhead lighting: (a to e) leptocephali, (f to j) metamorphosing larvae, (k to o) glass eels. White and black bars show daytime and nighttime distribution, respectively. Significances in distributional skew during daytime (dt), nighttime (nt) and significance between daytime and nighttime distribution $(\mathrm{dn})$ are shown in each panel (Fisher's exact test). Significance is shown by: ${ }^{*} \mathrm{p}<0.05$ or ${ }^{* *} \mathrm{p}<0.01 ;(-)$ : not significant

During the day, fish exhibited a significant bottomskewed distribution at 0.039 to $3.9 \mu \mathrm{mol}$ quanta $\mathrm{m}^{-2} \mathrm{~s}^{-1}$ light intensity levels $(\mathrm{p}<0.01$, Fisher's exact test, Fig. $2 \mathrm{~h}-\mathrm{j}$, white bars), and this tendency was more distinct at higher light intensities. In complete darkness $\left(0 \mu \mathrm{mol}\right.$ quanta $\left.\mathrm{m}^{-2} \mathrm{~s}^{-1}\right)$, fish were distributed randomly ( $p>0.84$, Fisher's exact test, Fig. 2f, white bars). In the night experiment, a similar bottom-skewed distribution was observed at 0.39 and $3.9 \mu \mathrm{mol}$ quanta $\mathrm{m}^{-2} \mathrm{~s}^{-1}$ light intensities ( $p<0.05$, Fisher's exact test, Fig. $2 \mathrm{i}, \mathrm{j}$, black bars), while no bottom-skewed distribution was observed at 0, 0.0039 and $0.039 \mu \mathrm{mol}$ quanta $\mathrm{m}^{-2} \mathrm{~s}^{-1}$ ( $p>0.39$, Fisher's exact test, Fig. 2f-h, black bars).

However, some metamorphosing larvae remained in the upper layers at 0.39 and $3.9 \mu \mathrm{mol}$ quanta $\mathrm{m}^{-2} \mathrm{~s}^{-1}$ light intensity (Fig. 2i,j), while all leptocephali were distributed in the lower layers (Fig. 2d,e). The individuals remaining in the upper layer were at a more advanced stage with lower PAL/TL (0.47 to 0.49) than were bottom-distributed fish (0.46 to 0.60 in PAL/TL), suggesting the descending behavior caused by strong negative phototaxis disappeared in the late stage of metamorphosis.
At the glass eel stage, eels exhibited a different distribution from those of leptocephali and metamorphosing leptocephali. Glass eels did not swim actively at any light intensity and exhibited a significant bottomskewed distribution during both day and night $(\mathrm{p}<$ 0.05, Fisher's exact test, Fig. 21-o). This tendency might not be caused by negative phototaxis because glass eels did not exhibit any phototaxis in the horizontal distribution experiment (Fig. 1m-r). In darkness $\left(0 \mu \mathrm{mol}\right.$ quanta $\left.\mathrm{m}^{-2} \mathrm{~s}^{-1}\right)$ they swam vigorously among the 3 to 4 layers and were distributed widely from the surface to the bottom during both daytime and nighttime ( $p>0.39$, Fisher's exact test, Fig. 2k), suggesting there was no circadian rhythm in glass eels, but that their activity was triggered by darkness.

\section{Swimming speed of leptocephali}

The swimming speed (Fig. 3) of leptocephali during their rising behavior in the water column in the nighttime vertical distribution experiment was $2.8 \pm 1.1 \mathrm{~cm}$ $\mathrm{s}^{-1}$ (SD) $\left(\mathrm{n}=11\right.$, median $2.25 \mathrm{~cm} \mathrm{~s}^{-1}$, range 1.9 to 


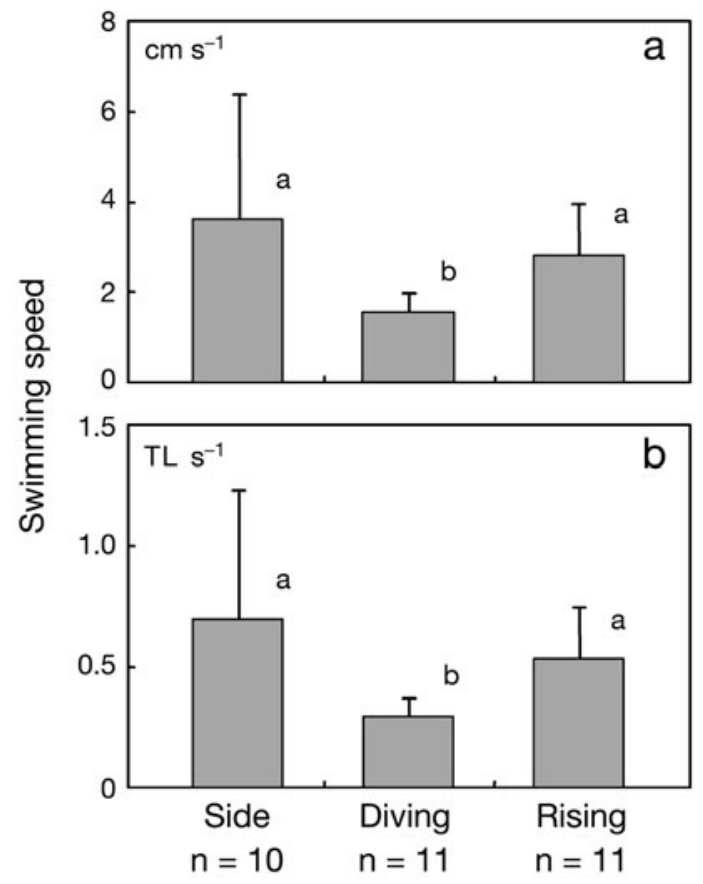

Fig. 3. Anguilla japonica. Swimming speeds of leptocephali moving in 3 directions: (a) in $\mathrm{cm} \mathrm{s}^{-1}$, (b) in total lengths (TL) $\mathrm{s}^{-1}$. Side movement occurred when a $3.9 \mu \mathrm{mol}$ quanta $\mathrm{m}^{-2} \mathrm{~s}^{-1}$ light stimulus from the left was moved to the right (also at $3.9 \mu \mathrm{mol}$ quanta $\mathrm{m}^{-2} \mathrm{~s}^{-1}$ ). Diving movement was when the lighting condition was changed from $0 \mu \mathrm{mol}$ quanta $\mathrm{m}^{-2} \mathrm{~s}^{-1}$ to $3.9 \mu \mathrm{mol}$ quanta $\mathrm{m}^{-2} \mathrm{~s}^{-1}$ overhead lighting. Rising movement was after the lighting condition was changed from $3.9 \mu \mathrm{mol}$ quanta $\mathrm{m}^{-2} \mathrm{~s}^{-1}$ overhead lighting to $0 \mu \mathrm{mol}$ quanta $\mathrm{m}^{-2} \mathrm{~s}^{-1}$. Error bars are SD. Significant differences (nonparametric Kruskal-Wallis test with Dunn's multiple comparison test, $\mathrm{p}<0.05)$ are shown by different letters in each panel

$\left.6.0 \mathrm{~cm} \mathrm{~s}^{-1}\right)$ or $0.53 \pm 0.21 \mathrm{TL} \mathrm{s}^{-1}(\mathrm{n}=11$, median 0.46 TL s ${ }^{-1}$, range 0.33 to $1.13 \mathrm{TL} \mathrm{s}^{-1}$ ) when the overhead lighting condition changed from $3.9 \mu \mathrm{mol}$ quanta $\mathrm{m}^{-2}$ $\mathrm{s}^{-1}$ to $0 \mu \mathrm{mol}$ quanta $\mathrm{m}^{-2} \mathrm{~s}^{-1}$. In contrast, during diving behavior their swimming speed was $1.6 \pm 0.4 \mathrm{~cm} \mathrm{~s}^{-1}$ ( $\mathrm{n}=11$, median $1.6 \mathrm{~cm} \mathrm{~s}^{-1}$, range 1.0 to $2.5 \mathrm{~cm} \mathrm{~s}^{-1}$ ) or $0.29 \pm 0.07 \mathrm{TL} \mathrm{s}^{-1}\left(\mathrm{n}=11\right.$, median $0.31 \mathrm{TL} \mathrm{s}^{-1}$, range 0.19 to $0.46 \mathrm{TL} \mathrm{s}^{-1}$ ) when the lighting condition changed from $0 \mu \mathrm{mol}$ quanta $\mathrm{m}^{-2} \mathrm{~s}^{-1}$ to $3.9 \mu \mathrm{mol}$ quanta $\mathrm{m}^{-2} \mathrm{~s}^{-1}$ overhead. In the horizontal distribution experiment, the mean swimming speed was $3.6 \pm$ $2.7 \mathrm{~cm} \mathrm{~s}^{-1}$ ( $\mathrm{n}=10$, median $3.2 \mathrm{~cm} \mathrm{~s}^{-1}$, range 0.9 to $\left.11.3 \mathrm{~cm} \mathrm{~s}^{-1}\right)$ or $0.69 \pm 0.52 \mathrm{TL} \mathrm{s}^{-1}(\mathrm{n}=10$, median $0.61 \mathrm{TL} \mathrm{s}^{-1}$, range 0.18 to $2.17 \mathrm{TL} \mathrm{s}^{-1}$ ) when the $3.9 \mu \mathrm{mol}$ quanta $\mathrm{m}^{-2} \mathrm{~s}^{-1}$ light direction changed from right to left. The speeds during the side to side movements and the rising behavior were significantly higher than those exhibited during diving $(\mathrm{p}<0.01$, Kruskal-Wallis test).

\section{DISCUSSION}

\section{Behavior of reared eel larvae}

This study is the first to describe the behavioral responses of Japanese eel larvae to photic stimuli, because these remarkable larvae are rarely caught alive and almost no aspect of their behavior and ecology has previously been studied (Pfeiler 1989, Mochioka 2003). However, due to the recent advances in rearing technology of eel larvae (Tanaka et al. 2003), it is now possible to observe and study their behavior in the laboratory. Although the ability to produce larvae in the laboratory has existed for about 30 yr (Yamamoto \& Yamauchi 1974), only recently have larvae actually survived through metamorphosis to the glass eel stage in captivity (Tanaka et al. 2003). Therefore, the present study was able for the first time to use individuals of 3 different larval stages adapted to a laboratory environment to test their behavioral responses to basic changes in lighting conditions. There is always a risk of not observing natural behavior due to artificial rearing conditions in the laboratory environment, but basic behaviors such as taxis reactions may be retained even in unnatural conditions. Other problems affecting this type of research are the constraints on the rearing of anguillid larvae and the difficulty of handling the fragile leptocephali in the laboratory, which limited the number of individuals used in the present experiments. Despite the statistical limitations of small sample sizes, the major behavioral patterns shown by the eel larvae in response to light were clear and can perhaps be validated with larger sample sizes in the future if rearing techniques continue to improve. However, it is possible that small sample sizes caused the underestimation of minor behaviors. As discussed in the following section, these experiments found clear evidence of phototactic behavior that appeared to change depending on the larval stage, a finding which is probably related to the behavioral ecology of the different stages in the ocean.

\section{Mechanism of diel vertical migration}

This study revealed that Japanese eel leptocephali have strong phototactic responses to light and exhibit both descending and ascending behaviors that can be induced by photic stimuli. There also appears to be an ontogenetic change in their phototactic behaviors that may be related to the vertical migration of leptocephali in the ocean and the inshore migration of glass eels as they approach coastal waters. Field studies have reported evidence of diel vertical migration of leptocephali of Japanese eel and other anguillid 
species from shallower depths in the upper $100 \mathrm{~m}$ at night to depths sometimes as deep as 250 to $300 \mathrm{~m}$ during the day (Schoth \& Tesch 1984, Castonguay \& McCleave 1987, Otake et al. 1998, Kajihara et al. 1988). The clear negative phototaxis observed in the leptocephali and metamorphosing larvae in the present study suggest that this behavioral response may be the overriding factor that causes their descending behavior, as has been suggested by studies on other types of zooplankton (Forward 1976, Ringelberg 1999). Field data from the Sargasso Sea have indicated that the rising of leptocephali occurred rapidly, mostly in the first hour after sunset, and the diving occurred more gradually (Castonguay \& McCleave 1987). However, if the ascending activity begins in darkness it can not be explained by simple phototaxis, because there is little light by which larvae can recognize a swimming direction. It is likely that negative geotaxis plays an important role as the indicator of swimming direction at least during darkness. Unfortunately, vertical profiles of light intensity have not been measured during studies on the depth distributions of leptocephali, so the field data can not be directly compared with our data in the laboratory.

Based on observations of descending and ascending behaviors induced by light in the laboratory in comparison with their diel vertical migration in nature, we speculate that eel larvae may dive into deeper layers exhibiting negative phototaxis at dawn, and rise up to shallower layers at dusk as light dissipates. Assuming, for example, that Japanese eel leptocephali are distributed in the upper $125 \mathrm{~m}$ layer in the daytime and in about the upper $75 \mathrm{~m}$ layer at night based on Otake et al. (1998), leptocephali can dive into the lower layer at a swimming speed of ca. $1.6 \mathrm{~cm} \mathrm{~s}^{-1}$ within about $60 \mathrm{~min}$ from dawn and rise up to an upper layer at a swimming speed of ca. $2.8 \mathrm{~cm} \mathrm{~s}^{-1}$ within about $30 \mathrm{~min}$ from dusk. Faster swimming speeds are also possible for these leptocephali, as has been observed recently for largersized leptocephali and glass eels of 2 species of eels in the Atlantic Ocean that were tested in the laboratory (Wuenschel \& Able 2008). A positive buoyancy of leptocephali (Tsukamoto et al. 2009) may tend to accelerate the ascending speed and reduce the diving speed. The faster side movement speed observed in the present study may be related to swimming behavior typically used as an escape reaction that was triggered in response to the bright light irradiated from an unexpected direction.

There were clear ontogenetic changes in phototaxis observed in this study that were similar to those reported in other aquatic organisms such as mussels (Dobretsov \& Miron 2001) and polychaetes (McCarthy et al. 2002). The leptocephalus larvae lost their strong negative phototaxis during the advanced metamor- phosing stage. Glass eels exhibited entirely different responses to photic stimuli to those of the leptocephali or metamorphosing leptocephali in both their horizontal and vertical distribution behaviors. In a $0.0039 \mu \mathrm{mol}$ quanta $\mathrm{m}^{-2} \mathrm{~s}^{-1}$ condition, glass eels generally lay on the bottom of the tank, while they showed random distribution throughout all the layers in darkness. This suggests that glass eels acquire a nocturnal and benthic behavior instead of the diel vertical migration that they display during the planktonic leptocephalus and metamorphosis stages. These characteristics probably contribute to the successful detrainment from the currents that transport leptocephali, enabling them to start their inshore migration toward coastal areas as glass eels.

\section{Circadian rhythm}

Our results suggest that the diel vertical migration of leptocephali is influenced by an endogenous circadian rhythm. Even at a constant $0 \mu \mathrm{mol}$ quanta $\mathrm{m}^{-2} \mathrm{~s}^{-1}$ light intensity level, the eel larvae at the leptocephalus and metamorphosing stages tended to be distributed in the surface layer at night, whereas they stayed in the bottom layer during daytime. These results suggest that the eel larvae have an endogenous biological clock that was entrained by a diel change in light levels during the rearing conditions. Consequently, the eel larvae rose rapidly to the surface under $0 \mu \mathrm{mol}$ quanta $\mathrm{m}^{-2} \mathrm{~s}^{-1}$ light intensity at night as a result of their biological clock and in accordance with environmental darkness. In contrast, they did not rise to the surface even under the $0 \mu \mathrm{mol}$ quanta $\mathrm{m}^{-2} \mathrm{~s}^{-1}$ condition in the daytime, because of the entrained circadian rhythm that keeps eels at deeper layers during the day and actively swimming downward against their positive buoyancy.

\section{Ecological significance}

The ontogenetic changes found in the present study for Japanese eels as regards their threshold for displaying descending behavior provided useful information that may have implications for the way in which different stages of eel larvae behave in the wild during the later stages of their leptocephalus migration. Late metamorphosing leptocephali did not descend into the bottom layer even at strong overhead lighting levels $\left(3.9 \mu \mathrm{mol}\right.$ quanta $\left.\mathrm{m}^{-2} \mathrm{~s}^{-1}\right)$. Changes in the visual system of eels and other fishes occur during metamorphosis from larvae to juveniles (Evans \& Fernald 1990), and the differences in phototactic responses between the late metamorphosing and non- or early metamorphosing larvae in the present study suggest that in nature 
late metamorphosing larvae would live at shallower layers from dawn to dusk than would leptocephali or early metamorphosing larvae. Staying at shallower layers may be advantageous for late metamorphosing leptocephali that need to transfer from the North Equatorial Current to the Kuroshio Current using an effect of Ekman transport caused by the trade winds (Kimura et al. 1994). Only Japanese eel larvae that successfully transfer between these currents can recruit to their growth habitats in East Asia. Ekman transport is effective only at layers shallower than $70 \mathrm{~m}$ in the ocean (Kimura et al. 1994), and large leptocephali (>40 mm TL) and metamorphosing larvae come up to around the $50 \mathrm{~m}$ depth contour at night (Kajihara et al. 1988). Therefore, an increase in light intensity threshold for descending behavior would seem to be useful for metamorphosing larvae as it would allow them to remain in the upper layer for Ekman transport as long as possible to facilitate successful entrainment into the Kuroshio Current and eventual recruitment.

Another factor besides larval transport that can be directly affected by the depth distribution of leptocephali is their feeding ecology. Little is known directly about the feeding behavior of leptocephali in nature, but based on scanning electron microscope observations of gut contents (Otake et al. 1993, Mochioka \& Iwamizu 1996) and stable nitrogen isotope analysis (Otake 1996), the diet of leptocephali is thought to be organic detritus, which is often referred to as 'marine snow' and composed of material such as fecal pellets, discarded larvacean houses and plankton remains (Mochioka \& Iwamizu 1996). In general, particulate organic carbon that includes marine snow and other particles exhibits maximum concentrations in the upper 100 m layer of the North Pacific subtropical gyre and along its western margins, and decreases sharply at deeper depths because the particles are produced in the euphotic layer near the sea surface and most are consumed by various organisms or decomposed by bacteria before reaching deeper layers (Ichikawa \& Nishizawa 1975, Ichikawa 1982, Hebel \& Karl 2001, Pilskaln et al. 2005). This suggests that the food of leptocephali is most abundant at depths shallower than $100 \mathrm{~m}$. Previous field data indicated that small Japanese eel leptocephali (10 to $20 \mathrm{~mm}$ TL) were distributed from 50 to $100 \mathrm{~m}\left(27\right.$ to $\left.29^{\circ} \mathrm{C}\right)$ at night, and from 100 to $150 \mathrm{~m}$ (24 to $27^{\circ} \mathrm{C}$ ) in the day (Otake et al. 1998). The Atlantic anguillid leptocephali and those of other families are also found primarily in the upper $100 \mathrm{~m}$ at night (Schoth \& Tesch 1984, Castonguay \& McCleave 1987).

The feeding behavior of leptocephali in nature has never been observed, although it has been observed in pike eel Mureanesox cinereus leptocephali caught in coastal waters and offered squid paste in the laboratory (Mochioka et al. 1993). Neither did we observe natural feeding behavior in the laboratory because in the present rearing method an unnatural strong light above the tank forces the larvae to dive to the bottom of the tank where they encounter the slurry-type food laid there. However, it is most likely that because of their highly developed visual system leptocephali are visual particulate feeders (Tomoda \& Uematsu 1996) and their apparent natural diet consists of free-floating particulate matter. They may move into the food-rich shallower layers at night to feed and grow in the warmer water temperatures. They may be able to feed at night because at least some marine snow has recently been shown to be bioluminescent due to microorganisms such as dinoflagellates attached to it (Herren et al. 2004). Even the discarded houses of some species of larvaceans are bioluminescent (Galt et al. 1985). This could allow leptocephali to visually target this food material in darkness. Therefore, the ascending behavior observed in the present study at night is likely an important behavior of leptocephali that enables them to use appropriate areas for feeding and rapid growth. Leptocephali probably dive into deeper layers during the day to escape predators that search for prey using vision, but whether they continue to feed during daytime on food particles found at lower densities under the low light conditions at the deeper depths is not known.

In the present study, several new findings are presented concerning the phototactic ontogeny, circadian rhythm and swimming speeds of leptocephali and the possible ecological significance of these behaviors. These results reveal a part of the larval ecology of anguillid eels that has remained poorly understood due to the limited insight that has been gained from field studies in the past. In future, this kind of behavioral research made possible by the recent developments in the rearing technology of eel larvae will greatly facilitate the understanding of their ecology .

Acknowledgements. We gratefully acknowledge Dr. H. Tana$\mathrm{ka}$, the leader of the eel reproduction group of the National Research Institute of Aquaculture, for kindly demontrating the techniques for rearing glass eels from eggs. This study is contribution no. 35 from the IRAGO Institute.

\section{LITERATURE CITED}

Arai T, Otake T, Tsukamoto K (1997) Drastic changes in otolith microstructure and microchemistry accompanying the onset of metamorphosis in the Japanese eel Anguilla japonica. Mar Ecol Prog Ser 161:17-22

Blaxter JHS (1975) The role of light in the vertical migration of fish. In: Evans GC, Bainbrige R, Rackham O (eds) Light as an ecological factor II. Blackwell, Oxford, p 189-210 
Castonguay M, McCleave JD (1987) Vertical distributions, diel and ontogenetic vertical migrations and net avoidance of leptocephali of Anguilla and other common species in the Sargasso Sea. J Plankton Res 9:195-214

Cheng PW, Tzeng WN (1996) Timing of metamorphosis and estuarine arrival across the dispersal range of the Japanese eel Anguilla japonica. Mar Ecol Prog Ser 131:87-96

Crisp DJ (1974) Factors influencing settlement of marine invertebrate larvae. In: Grant PT, Mackie AM (eds) Chemoreception in marine organisms. Academic Press, London, p 177-265

> Dobretsov SV, Miron G (2001) Larval and post-larval vertical distribution of the mussel Mytilus edulis in the White Sea. Mar Ecol Prog Ser 218:179-187

Evans BI, Fernald RD (1990) Metamorphosis and fish vision. J Neurobiol 21:1037-1052

Forward RB Jr (1976) Light and diurnal vertical migration: photobehavior and photophysiology of plankton. Photochem Photobiol Rev 1:157-209

Galt CP, Grober MS, Sykes PF (1985) Taxonomic correlates of bioluminescence among appendicularians (Urochordata: Larvacea). Biol Bull (Woods Hole) 168:125-134

$>$ Hays GC (2003) A review of the adaptive significance and ecosystem consequences of zooplankton diel vertical migrations. Hydrobiologia 503:163-170

Hebel DV, Karl DM (2001) Seasonal, interannual and decadal variations in particulate matter concentrations and composition in the subtropical North Pacific Ocean. Deep-Sea Res II 48:1669-1695

Herren CM, Alldredge AL, Case JF (2004) Coastal bioluminescent marine snow: fine structure of bioluminescence distribution. Cont Shelf Res 24:413-429

Horie N, Utoh T, Mikawa N, Yamada Y and others (2008) Influence of artificial fertilization methods of the hormonetreated Japanese eel Anguilla japonica upon the quality of eggs and larvae (comparison between stripping-insemination and spontaneous spawning methods). Bull Jpn Soc Sci Fish 74:26-35 (in Japanese)

Ichikawa T (1982) Particulate organic carbon and nitrogen in the adjacent seas of the Pacific Ocean. Mar Biol 68: $49-60$

Ichikawa T, Nishizawa S (1975) Particulate organic carbon and nitrogen in the eastern Pacific Ocean. Mar Biol 29: 129-138

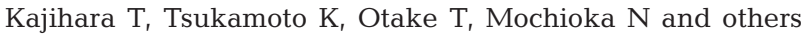
(1988) Sampling leptocephali with reference to the diel vertical migration and the gears. Nippon Suisan Gakkai Shi 54:941-946

Kimura S, Tsukamoto K (2006) The salinity front in the North Equatorial Current: a landmark for the spawning migration of the Japanese eel (Anguilla japonica) related to the stock recruitment. Deep-Sea Res II 53:315-325

Kimura S, Tsukamoto K, Sugimoto T (1994) A model for the larval migration of the Japanese eel: roles of the trade winds and salinity front. Mar Biol 119:185-190

Kimura S, Döös K, Coward AC (1999) Numerical simulation to resolve the issue of downstream migration of the Japanese eel. Mar Ecol Prog Ser 186:303-306

Lampert W (1989) The adaptive significance of diel vertical migration of zooplankton. Funct Ecol 3:21-27

McCarthy DA, Forward RB Jr, Young CM (2002) Ontogeny of phototaxis and geotaxis during larval development of the sabellariid polychaete Phragmatopoma lapidosa. Mar Ecol Prog Ser 241:215-220

McCleave JD (2003) Spawning area of the Atlantic eels. In: Aida K, Tsukamoto K, Yamauchi K (eds) Eel biology. Springer-Verlag, Tokyo, p 141-155
Mochioka N (2003) Leptocephali. In: Aida K, Tsukamoto K, Yamauchi K (eds) Eel biology. Springer-Verlag, Tokyo, p 51-60

Mochioka N, Iwamizu M (1996) Diet of anguillid larvae: Leptocephali feed selectively on larvacean houses and fecal pellets. Mar Biol 125:447-452

Mochioka N, Iwamizu M, Kanda T (1993) Leptocephalus eel larvae will feed in aquaria. Environ Biol Fishes 36: $381-384$

Naylor E (2006) Orientation and navigation in coastal and estuarine zooplankton. Mar Freshw Behav Physiol 39: $13-24$

Otake T (1996). Larval diet in Anguilliformes. In: Tabeta O (ed) Early life history and prospects of seed production of the Japanese eel Anguilla japonica. Kouseishya Kouseikaku, Tokyo, p 33-43 (in Japanese)

Otake T, Nogami K, Maruyama K (1993) Dissolved and particulate organic matter as possible food sources for eel leptocephali. Mar Ecol Prog Ser 92:27-34

Otake T, Ishii T, Nakahara M, Nakamura R (1994) Drastic changes in otolith strontium/calcium ratios in leptocephali and glass eels of Japanese eel Anguilla japonica. Mar Ecol Prog Ser 112:189-193

Otake T, Inagaki T, Hasumoto H, Mochioka N, Tsukamoto K (1998) Diel vertical distribution on Anguilla japonica leptocephali. Ichthyol Res 45:208-211

Otake T, Miller MJ, Inagaki T, Minagawa G and others (2006) Evidence for migration of metamorphosing larvae of Anguilla japonica in the Kuroshio. Coast Mar Sci 30: 453-458

Pearre S Jr (2003) Eat and run? The hunger/satiation hypothesis in vertical migration: history, evidence and consequences. Biol Rev Camb Philos Soc 78:1-79

Pfeiler E (1989) Sensory systems and behavior of premetamorphic and metamorphic leptocephalus larvae. Brain Behav Evol 34:25-34

- Pilskaln CH, Villareal TA, Dennett M, Darkangelo-Wood C, Meadows G (2005) High concentrations of marine snow and diatom algal mats in the North Pacific Subtropical Gyre: implications for carbon and nitrogen cycles in the oligotrophic ocean. Deep-Sea Res I 52:2315-2332

Ringelberg J (1995) Changes in light intensity and diel vertical migration: a comparison of marine and freshwater environments. J Mar Biol Assoc UK 75:15-25

Ringelberg J (1999) The photobehavior of Daphnia spp. as a model to explain diel vertical migration in zooplankton. Biol Rev Camb Philos Soc 74:397-423

Schoth M, Tesch FW (1984) The vertical distribution of small O-group Anguilla larvae in the Sargasso Sea with reference to other anguilliform leptocephali. Meeresforschung 30:188-195

Stancyk SE, Feller RJ (1986) Transport of non-decapod invertebrate larvae in estuaries: an overview. Bull Mar Sci 39: $257-268$

Tachiki H, Nakagawa T (1993) Induction of spawning in female cultured eel Anguilla japonica. Bull Aichi Fish Res Inst 1:79-83 (in Japanese)

Tanaka H, Kagawa H, Ohta H, Unuma T, Nomura K (2003) The first production of glass eel in captivity: fish reproductive physiology facilitates great progress in aquaculture. Fish Physiol Biochem 28:493-497

Tomoda H, Uematsu K (1996) Morphogenesis of the brain in larval and juvenile Japanese eels, Anguilla japonica. Brain Behav Evol 47:33-41

Tsukamoto K (1990) Recruitment mechanism of the eel, Anguilla japonica, to the Japanese coast. J Fish Biol 36: 659-671 
Tsukamoto K (1992) Discovery of the spawning area for Japanese eel. Nature 356:789-791

Tsukamoto K (2006) Spawning of eels near a seamount. Nature 439:929

Tsukamoto K, Lee TW, Fricke H (2003) Spawning area of the Japanese eel. In: Aida K, Tsukamoto K, Yamauchi K (eds) Eel biology. Springer-Verlag, Tokyo, p 121-140

Tsukamoto K, Yamada Y, Okamura A, Kaneko T and others (2009) Positive buoyancy in eel leptocephali: an adapta-

Editorial responsibility: Nick Tolimieri,

Seattle, Washington, USA tion for life in the ocean surface layer. Mar Biol 156: 835-846

Wuenschel MJ, Able KW (2008) Swimming ability of eels (Anguilla rostrata, Conger oceanicus) at estuarine ingress: contrasting patterns of cross-shelf transport? Mar Biol 154: $775-786$

Yamamoto K, Yamauchi K (1974) Sexual maturation of Japanese eel and production of eel larvae in the aquarium. Nature 251:220-222

Submitted: May 26, 2008; Accepted: December 26, 2008 Proofs received from author(s): March 23, 2009 